\title{
Stereochemistry of Transition Metal Dinitrosyl Complexes. A New Molecular Orbital Rationale for the Attracto and Repulso Conformations
}

\begin{abstract}
Abhik Ghosh*,a and Jeanet Conradie*a,b
a'Department of Chemistry, University of Tromsø, N-9037 Tromsø, Norway; abhik.ghosh@uit.no (AG). ${ }^{b}$ Department of Chemistry, University of the Free State, 9300 Bloemfontein, Republic of South Africa; conradj@ufs.ac.za (JC).
\end{abstract}

Abstract. Transition metal dinitrosyl complexes constitute a fairly large class of compounds, exemplified by some 500 structures in the Cambridge Structural Database. While many of the complexes exhibit a claw-like cis-attracto conformation, a handful of them exhibit a peculiar repulso conformation, in which the two NO groups are splayed outward and away from each other. Surprisingly, no computational study to date has attempted to explain the existence of these two limiting conformations of cis-dinitrosyl complexes. Careful examination of the large body of structural data and DFT-based molecular orbital analyses have identified both specific EnemarkFeltham electron counts and metal-ligand orbital interactions as crucial to each of the two conformations. Thus, the common attracto conformation, which is favored by as many as four metal(d)- $\mathrm{NO}\left(\pi^{*}\right)$ orbital interactions, is observed most characteristically in four- and fivecoordinate cis- $\left\{\mathrm{M}(\mathrm{NO})_{2}\right\}^{8}$ complexes. The rarer repulso conformation, characterized by an unusually wide $\mathrm{NMN}^{\prime}$ angle, appears to be typical of pseudotetrahedral $\left\{\mathrm{M}(\mathrm{NO})_{2}\right\}^{10}$ complexes involving $4 \mathrm{~d}$ and $5 \mathrm{~d}$ transition metals. These complexes exhibit an $\mathrm{a}_{1}$-symmetry (under a $C_{2 \mathrm{v}}$ molecular point group) metal(d)- $\mathrm{NO}\left(\pi^{*}\right)$ orbital interaction that uniquely favors a repulso geometry. This orbital interaction, however, appears to be weaker for $3 \mathrm{~d}$ orbitals, which are significantly smaller than $4 \mathrm{~d}$ and $5 \mathrm{~d}$ orbitals. Pseudotetrahedral $\left\{\mathrm{M}(\mathrm{NO})_{2}\right\}^{10}$ complexes involving a $3 \mathrm{~d}$ transition metal accordingly thus tend to exhibit an attracto conformation for hard, nitrogenbased supporting ligands but repulso-like/borderline conformations for soft phosphine and thioether-type supporting ligands. 


\section{Introduction.}

Few areas of inorganic chemistry represent a convergence of fundamental questions of structure and bonding and profound biological relevance as the chemistry of transition metal nitrosyls. ${ }^{1,2,3,4}$ Transition metal dinitrosyl complexes beautifully epitomize this convergence. ${ }^{5,6,7}$ Best known among this diverse class of complexes are the $S=1 / 2\left\{\mathrm{Fe}(\mathrm{NO})_{2}\right\}^{9}$ dinitrosyl iron complexes (DNICs), which rank among the most abundant nitrosylated species in the cellular environment. ${ }^{8,9,10}$ The superscript numeral refers to the Enemark-Feltham electron count, which is the sum of the number of metal d electrons and the number of $\mathrm{NO} \pi^{*}$ electrons; ${ }^{11}$ the $\left\{\mathrm{Fe}(\mathrm{NO})_{2}\right\}^{9}$ notation is thus equivalent ' $\mathrm{Fe}(\mathrm{I})\left(\mathrm{d}^{7}\right)+2 \mathrm{NO}$ ', DNICs are formed via NO-induced degradation of iron-sulfur clusters and, as reservoirs of $\mathrm{NO}$, are thought to play a protective role against oxidative stress. The majority of structurally characterized transition metal dinitrosyls, including the DNICs, exhibit a cis-attracto $\left(\angle \mathrm{OMO}^{\prime}<\angle \mathrm{NMN}^{\prime}\right)$ stereochemistry. Both the cis-repulso $\left(\angle \mathrm{OMO}^{\prime}>\angle \mathrm{NMN}^{\prime}\right)$ and trans stereochemistries are less common (Scheme 1). The existence of the attracto and repulso conformations, somewhat reminiscent of the recently introduced concept of bond angle isomers or akamptisomers, ${ }^{12}$ has long piqued the curiosity of transition metal nitrosyl researchers, ${ }^{5,1}, 13$ but the subject has remained essentially untouched by quantum chemical studies. The sole, major discussion of the subject, by Martin and Taylor, consists of qualitative symmetry arguments and does not appear to be based on actual quantum chemical computations (let alone geometry optimizations). To shed light on the mystery, we surveyed the 500 or so transition metal dinitrosyl structures in the Cambridge Structural Database (CSD) and attempted to discern patterns, an exercise that proved rewarding. Subsequently, we carried out a density functional theory (DFT) study of a representative selection of cis-dinitrosyl complexes, including both attracto and repulso conformations, and carefully examined their frontier molecular orbitals (MOs). Together, the two approaches have yielded a new explanation for the stereochemical diversity of $c i s$-dinitrosyls that differs substantively from that proposed earlier. ${ }^{13}$

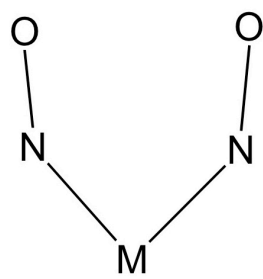

attracto

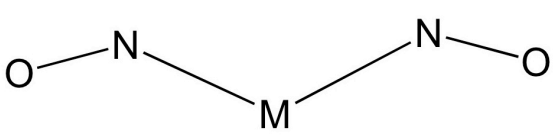

repulso

Scheme 1 
Table 1. Crystallographic and DFT structural data ( $\AA$, deg) for representative four- and fivecoordinate cis-dinitrosyl complexes.

\begin{tabular}{|c|c|c|c|c|c|c|c|c|}
\hline & Formula & $d(\mathrm{M}-\mathrm{N})$ & $\angle \mathrm{NMN}^{\prime}$ & $\angle \mathrm{OMO}^{\prime}$ & $\mathrm{M}-\mathrm{N}-\mathrm{O}$ & Description & Source & $\operatorname{Ref}^{\mathrm{a}}$ \\
\hline $\multirow[t]{4}{*}{\mathrm{Mn}(\mathrm{NO})_{2}}^{8}$ & {$\left[\mathrm{MnH}(\mathrm{NO})_{2}\left(\mathrm{PMe}_{3}\right)_{2}\right]$} & 1.652 & 121.4 & 115.7 & 173.1 & attracto & DFT & $t w$ \\
\hline & {$\left[\mathrm{MnH}(\mathrm{NO})_{2}\left(\mathrm{PMe}_{3}\right)_{2}\right]$} & 1.661 & 121.7 & 115.9 & 173.0 & attracto & YERWAT & 14 \\
\hline & {$\left[\mathrm{MnL}(\mathrm{NO})_{2}\left(\mathrm{PMe}_{3}\right)_{2}\right]$} & 1.648 & 116.9 & 109.2 & 170.7 & attracto & YERWEX & 14 \\
\hline & {$\left[\mathrm{MnL}^{\prime}(\mathrm{NO})_{2}\left(\mathrm{PMe}_{3}\right)_{2}\right]$} & 1.666 & 118.4 & 111.2 & 171.1 & attracto & YERWIB & 14 \\
\hline $\multirow[t]{2}{*}{\operatorname{Re}(\mathrm{NO})_{2}}^{8}$ & {$\left[\mathrm{Re}(\mathrm{NO})_{2}\left(\mathrm{PMe}_{3}\right)_{2}\right]^{+}$} & 1.772 & 117.1 & 102.4 & 161.6 & attracto & DFT & tw \\
\hline & {$\left[\mathrm{Re}(\mathrm{NO})_{2}\left(\mathrm{PCy}_{3}\right)_{2}\right]^{+}$} & 1.751 & 115.9 & 104.9 & 166.3 & attracto & GOXQAL & 15 \\
\hline $\multirow[t]{2}{*}{\mathrm{Os}(\mathrm{NO})_{2}}^{8}$ & {$\left[\mathrm{Os}(\mathrm{NO})_{2}(\mathrm{Cl})\left(\mathrm{PMe}_{3}\right)_{2}\right]$} & 1.777 & 118.6 & 108.4 & 167.2 & attracto & DFT & $t w$ \\
\hline & {$\left[\mathrm{Os}(\mathrm{NO})_{2}(\mathrm{Cl})\left(\mathrm{PPh}_{3}\right)_{2}\right]$} & 1.798 & 123.6 & 116.6 & 170.8 & attracto & JAXHOF & 16 \\
\hline $\multirow[t]{2}{*}{\mathrm{Fe}(\mathrm{NO})_{2}}^{9}$ & {$\left[\mathrm{Fe}(\mathrm{NO})_{2}(\right.$ nacnac $\left.)\right]$} & 1.672 & 107.8 & 90.5 & 159.0 & attracto & DFT & $t w$ \\
\hline & {$\left[\mathrm{Fe}(\mathrm{NO})_{2}(\right.$ nacnac $\left.)\right]$} & 1.692 & 114.3 & 103.3 & 166.4 & attracto & NUDLII & 17 \\
\hline $\multirow[t]{2}{*}{\mathrm{Fe}(\mathrm{NO})_{2}}^{9}$ & {$\left[\mathrm{Fe}(\mathrm{NO})_{2}(\mathrm{Im})_{2}(\mathrm{ONO})\right]$} & 1.703 & 104.7 & 82.7 & 153.1 & attracto & DFT & $t w$ \\
\hline & {$\left[\mathrm{Fe}(\mathrm{NO})_{2}(1-\mathrm{MeIm})_{2}(\mathrm{ONO})\right]$} & 1.721 & 103.4 & 80.0 & 150.2 & attracto & YOYMIJ & 18 \\
\hline $\multirow[t]{2}{*}{\mathrm{Fe}(\mathrm{NO})_{2}}^{10}$ & {$\left[\mathrm{Fe}(\mathrm{NO})_{2}\right.$ bipy $]$} & 1.631 & 111.6 & 103.8 & 170.7 & attracto & DFT & $t w$ \\
\hline & {$\left[\mathrm{Fe}(\mathrm{NO})_{2}\right.$ bipy $]$} & 1.649 & 114.4 & 104.3 & 167.8 & attracto & BUPNIK & 19 \\
\hline $\multirow[t]{2}{*}{\mathrm{Fe}(\mathrm{NO})_{2}}^{10}$ & {$\left[\mathrm{Fe}(\mathrm{NO})_{2}(\text { nacnac })\right]^{-}$} & 1.629 & 108.2 & 94.1 & 163.3 & attracto & DFT & $t w$ \\
\hline & {$\left[\mathrm{Fe}(\mathrm{NO})_{2}(\text { nacnac })\right]^{-}$} & 1.659 & 109.1 & 95.9 & 164.2 & attracto & NUDLOO & 17 \\
\hline $\multirow[t]{2}{*}{\mathrm{Fe}(\mathrm{NO})_{2}}^{10}$ & {$\left[\mathrm{Fe}(\mathrm{NO})_{2}\left\{o-\mathrm{C}_{6} \mathrm{H}_{4}\left(\mathrm{PPh}_{2}\right)_{2}\right\}\right]$} & 1.636 & 120.0 & 116.3 & 175.5 & borderline & DFT & $t w$ \\
\hline & {$\left[\mathrm{Fe}(\mathrm{NO})_{2}\left\{o-\mathrm{C}_{6} \mathrm{H}_{4}\left(\mathrm{PPh}_{2}\right)_{2}\right\}\right]$} & 1.644 & 129.5 & 129.8 & 181.4 & borderline & NODKEY & 20 \\
\hline $\multirow[t]{2}{*}{\mathrm{Co}(\mathrm{NO})_{2}}^{10}$ & {$\left[\mathrm{Co}(\mathrm{NO})_{2}\left\{\mathrm{P}(\mathrm{OMe})_{3}\right\}_{2}\right]^{+}$} & 1.653 & 131.3 & 133.9 & 184.2 & borderline & DFT & $t w$ \\
\hline & {$\left[\mathrm{Co}(\mathrm{NO})_{2}\left\{\mathrm{P}(\mathrm{OMe})_{3}\right\}_{2}\right]^{+}$} & 1.604 & 128.0 & 129.2 & 181.6 & borderline & CAXRIC & 21 \\
\hline $\multirow[t]{2}{*}{\mathrm{Os}(\mathrm{NO})_{2}}^{10}$ & {$\left[\mathrm{Os}(\mathrm{NO})_{2}\left(\mathrm{PMe}_{3}\right)_{2}\right]$} & 1.792 & 135.0 & 135.6 & 180.8 & borderline & DFT & $t w$ \\
\hline & {$\left[\mathrm{Os}(\mathrm{NO})_{2}\left(\mathrm{PPh}_{3}\right)_{2}\right]$} & 1.773 & 139.1 & 140.7 & 183.6 & borderline & NTPOSB & 22 \\
\hline $\multirow[t]{3}{*}{\mathrm{Co}(\mathrm{NO})_{2}}^{10}$ & {$\left[\mathrm{Co}(\mathrm{NO})_{2}\left(\mathrm{PMe}_{3}\right)_{2}\right]^{+}$} & 1.649 & 132.0 & 134.6 & 183.2 & borderline & DFT & $t w$ \\
\hline & {$\left[\mathrm{Co}(\mathrm{NO})_{2}(\mathrm{dppe})\right]^{+}$} & 1.664 & 131.7 & 136.0 & 185.6 & repulso & NDPECO & 23 \\
\hline & {$\left[\mathrm{Co}(\mathrm{NO})_{2}\left(\mathrm{PPh}_{3}\right)_{2}\right]^{+}$} & 1.644 & 136.6 & 144.0 & 189.0 & repulso & NPCOFP & 24 \\
\hline $\multirow[t]{2}{*}{\mathrm{Rh}(\mathrm{NO})_{2}}^{10}$ & {$\left[\mathrm{Rh}(\mathrm{NO})_{2}\left(\mathrm{PMe}_{3}\right)_{2}\right]^{+}$} & 1.828 & 148.4 & 160.7 & 195.8 & repulso & DFT & $t w$ \\
\hline & {$\left[\mathrm{Rh}(\mathrm{NO})_{2}\left(\mathrm{PPh}_{3}\right)_{2}\right]^{+}$} & 1.818 & 157.5 & 173.7 & 201.0 & repulso & DNTPRH & 25 \\
\hline $\multirow[t]{2}{*}{\mathrm{Ir}(\mathrm{NO})_{2}}^{10}$ & {$\left[\operatorname{Ir}(\mathrm{NO})_{2}\left(\mathrm{PMe}_{3}\right)_{2}\right]^{+}$} & 1.809 & 145.6 & 153.4 & 189.9 & repulso & DFT & $t w$ \\
\hline & {$\left[\operatorname{Ir}(\mathrm{NO})_{2}\left(\mathrm{PPh}_{3}\right)_{2}\right]^{+}$} & 1.771 & 154.1 & 167.5 & 196.5 & repulso & NOTPIR & 26 \\
\hline
\end{tabular}

${ }^{\mathrm{a}} t w=$ this work

\section{Results and Discussion}

Table 1 summarizes key crystallographic structural parameters and the corresponding scalar-relativistic DFT (OLYP $27,28 /$ STO-TZP) optimized values for a set of exemplary, four- and five-coordinate complexes..$^{14^{-26}}$ The choice of the OLYP functional for this study was based both on the generally excellent performance of GGA functionals based on the OPTX ${ }^{27}$ exchange 
functional for transition metal systems ${ }^{29,30,31,32}$ and on extensive calibration studies on nitrosyls. ${ }^{33,34,35,36,37}$ The assembled data suggest that the the attracto conformation is most characteristic for four- and five-coordinate $\left\{\mathrm{M}(\mathrm{NO})_{2}\right\}^{8}$ complexes, while the less common repulso conformation is largely limited to pseudotetrahedral $\left\{\mathrm{M}(\mathrm{NO})_{2}\right\}^{10}$ complexes. That said, far from all $\left\{\mathrm{M}(\mathrm{NO})_{2}\right\}^{10}$ complexes are repulso; like the $\left\{\mathrm{Fe}(\mathrm{NO})_{2}\right\}^{9} \mathrm{DNICs}$, certain $\left\{\mathrm{Fe}(\mathrm{NO})_{2}\right\}^{10}$ derivatives are also attracto.

In this study, we have not concerned ourselves with six-coordinate $\left\{\mathrm{M}(\mathrm{NO})_{2}\right\}^{6}\left(\mathrm{M}=\mathrm{V},{ }^{38}\right.$ $\mathrm{Cr},{ }^{39,40} \mathrm{Mo}^{41}$ ) complexes, the majority of which exhibit linear nitrosyls; the structures of these species are readily understood in terms of elementary backbonding considerations. The unambiguous attracto conformation of an $\left\{\mathrm{Mo}(\mathrm{NO})_{2}\right\}^{6}$ porphyrin complex (CSD: DNSPMO $)^{42}$ was analyzed in an earlier DFT study and is thought to reflect stereoelectronic constraints imposed by the porphyrin ligand. ${ }^{43}$ Also excluded from this study are six-coordinate transdinitrosyl species, examples of which are provided by $\left\{\mathrm{M}(\mathrm{NO})_{2}\right\}^{8}$ derivatives of porphyrin- and phthalocyanine-type ligands. ${ }^{44,45,46,47,48,49}$

As shown in Table 1, the OLYP/STO-TZP calculations do an excellent job of reproducing the key structural parameters of dinitrosyl complexes, specifically their attracto, repulso, or borderline conformations. ${ }^{50}$ Thus, consistent with experiment (CSD: GOXQAL, NOTPIR, and BUPNIK), the optimized geometries for $\left[\mathrm{Re}(\mathrm{NO})_{2}\left(\mathrm{PMe}_{3}\right)_{2}\right]^{+}$and $\left[\mathrm{Fe}(\mathrm{NO})_{2}(\text { bipy })\right]^{0}$ correspond to an attracto conformation and that for $\left[\operatorname{Ir}(\mathrm{NO})_{2}\left(\mathrm{PMe}_{3}\right)_{2}\right]^{+}$corresponds to a repulso conformation. Indeed, the excellent agreement between optimized and experimental molecular geometries provides powerful support for the validity of the calculated MO picture in each case. To our considerable convenience, the key d-based MOs were invariably found among the frontier MOs of the complexes. These MOs are depicted for $\left[\operatorname{Re}(\mathrm{NO})_{2}\left(\mathrm{PMe}_{3}\right)_{2}\right]^{+},\left[\operatorname{Ir}(\mathrm{NO})_{2}\left(\mathrm{PMe}_{3}\right)_{2}\right]^{+}$, and $\left[\mathrm{Fe}(\mathrm{NO})_{2}(\text { bipy })\right]^{0}$ in Figures 1-3, while the corresponding MO energy levels are depicted in Figure 4. To our great satisfaction, ${ }^{51,52,5354,55,56,57,58}$ these analyses indeed provided the critical insight into the driving forces underlying the attracto and repulso stereochemistries.

For each complex, the gross topological characteristics of the five metal d-based frontier MOs may be best described in terms of their $C_{2 v}$ irreducible representations. Thus, two of the MOs transform as $a_{1}$, while the other three transform as $a_{2}, b_{1}$, and $b_{2}$. The nature of the metal(d)$\mathrm{NO}\left(\pi^{*}\right)$ interactions in latter three MOs (Figures 1-3) are obvious and do not merit much comment. On the other hand, the two $\mathrm{a}_{1}$-symmetry MOs are mutually rotated in the attracto and repulso conformations. For the two attracto complexes $\left[\operatorname{Re}(\mathrm{NO})_{2}\left(\mathrm{PMe}_{3}\right)_{2}\right]^{+}$and $\left[\mathrm{Fe}(\mathrm{NO})_{2}(\text { bipy })\right]^{0}$, 
four of the five d-based MOs involve strong metal(d)-NO( $\left.\pi^{*}\right)$ bonding interactions, whereas the last and highest-energy MO (actually the LUMO for the Re complex), which transforms as $\mathrm{a}_{1}$, is essentially nonbonding. Recently, Ye and Neese have observed the same "one-over-four" energy level pattern for a DNIC model complex. ${ }^{59}$ The metal(d)-NO $\left(\pi^{*}\right)$ bonding interactions in the four lower d-based MOs provide a clear rationale for the attracto conformations of these two complexes.

Now, for the repulso $\left\{\mathrm{M}(\mathrm{NO})_{2}\right\}^{10}$ complex $\left[\operatorname{Ir}(\mathrm{NO})_{2}\left(\mathrm{PMe}_{3}\right)_{2}\right]^{+}$, the $\mathrm{a}_{1}$-symmetry metal $\left(\mathrm{d}_{\mathrm{x} 2-}\right.$ y2) $-\mathrm{NO}\left(\pi^{*}\right)$ orbital interaction (top left in Figure 2) is expected to be strongly favored by a wide $\mathrm{NMN}^{\prime}$ angle, which is indeed what is observed for all repulso and borderline structures listed in Table 1. For four- and five-coordinate $\left\{\mathrm{M}(\mathrm{NO})_{2}\right\}^{8}$ complexes such as $\left[\mathrm{Re}(\mathrm{NO})_{2}\left(\mathrm{PMe}_{3}\right)_{2}\right]^{+}$, this orbital interaction corresponds to an unoccupied MO, which does not have any bearing on the observed molecular conformation. It is worth emphasizing that this rationale for the repulso conformation is novel and different from that offered by Martin and Taylor.
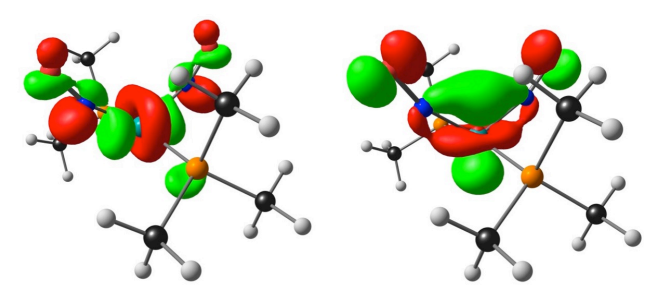

$$
\mathrm{d}_{\mathrm{x} 2-\mathrm{y} 2}\left(\mathrm{a}_{1}\right) \quad \mathrm{d}_{\mathrm{z} 2}\left(\mathrm{a}_{1}\right)
$$

\section{unoccupied}
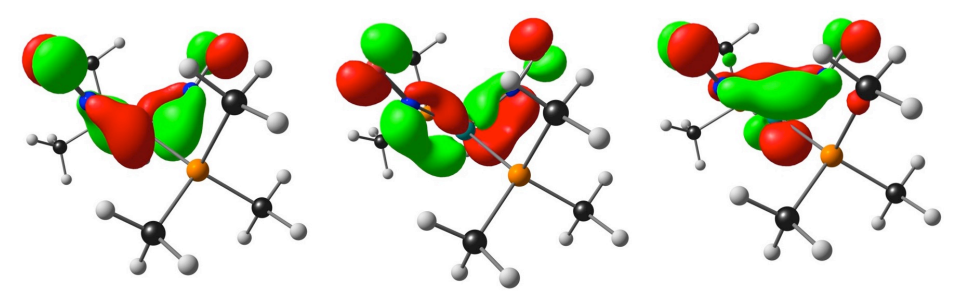

$$
d_{x y}\left(a_{2}\right)
$$

$$
d_{x z}\left(b_{1}\right)
$$

$$
d_{y z}\left(b_{2}\right)
$$

Figure 1. Key metal d-based MOs of $\left[\mathrm{Re}(\mathrm{NO})_{2}\left(\mathrm{PMe}_{3}\right)_{2}\right]^{+}$. Contour $=0.06 \mathrm{e} / \AA^{3}$. 

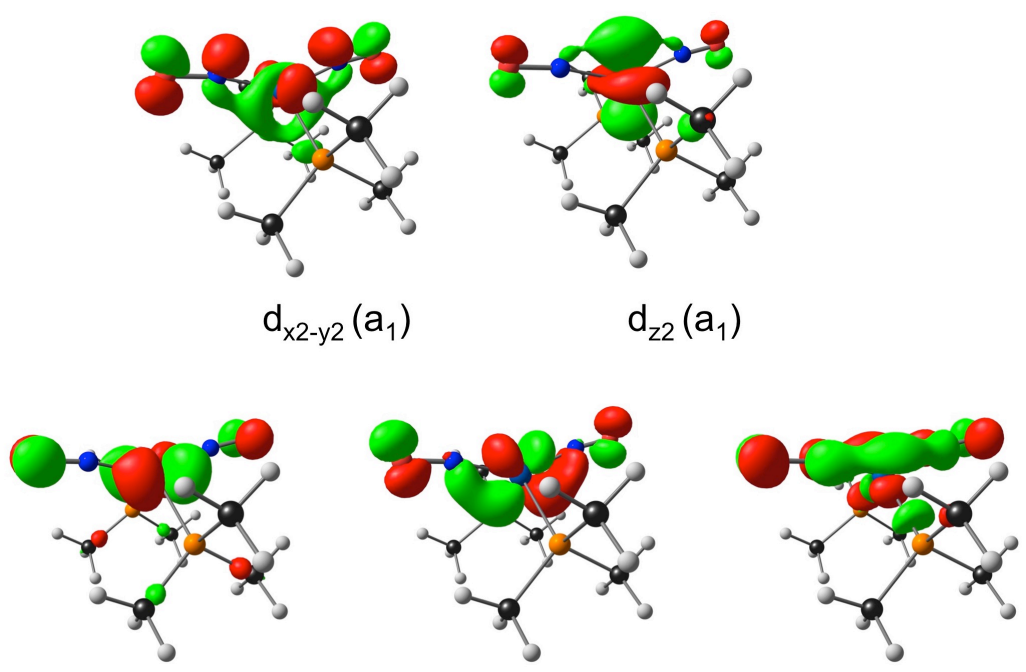

$d_{x y}\left(a_{2}\right)$

$d_{x z}\left(b_{1}\right)$

$d_{y z}\left(b_{2}\right)$

Figure 2. The metal d-based MOs of $\left[\operatorname{Ir}(\mathrm{NO})_{2}\left(\mathrm{PMe}_{3}\right)_{2}\right]^{+}$. Contour $=0.06 \mathrm{e} / \AA^{3}$.
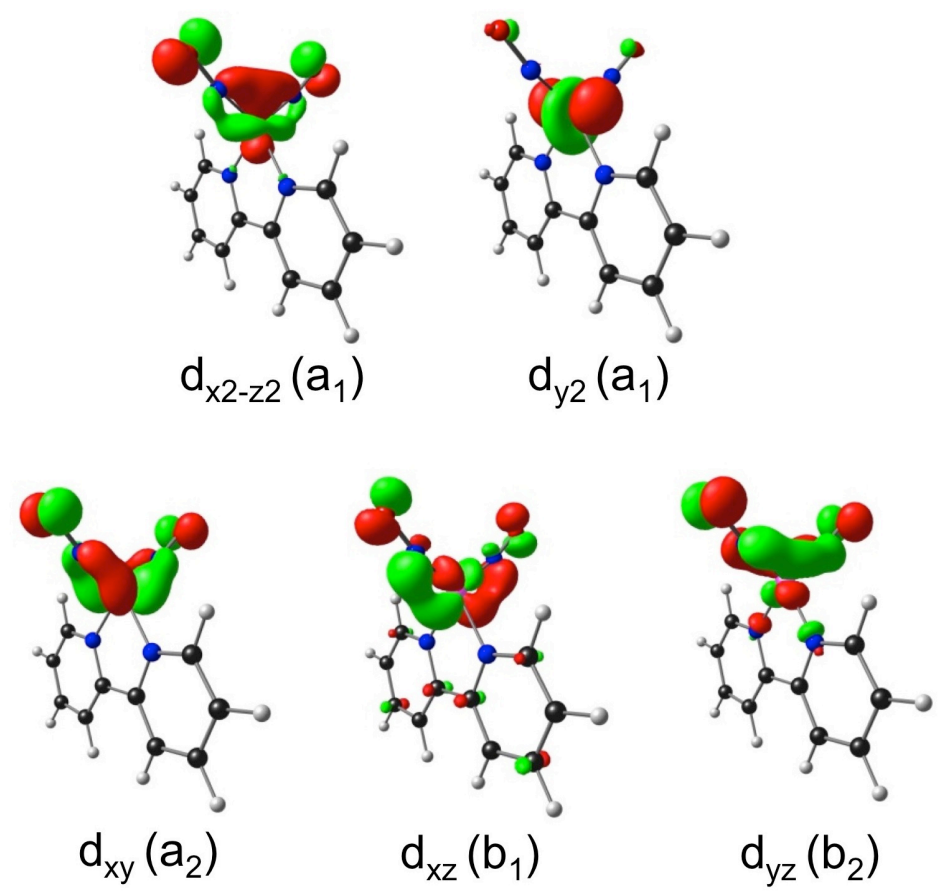

Figure 3. The metal d-based MOs of $\left[\mathrm{Fe}(\mathrm{NO})_{2}(\text { bipy })\right]^{0}$. Contour $=0.06 \mathrm{e} / \AA^{3}$. 


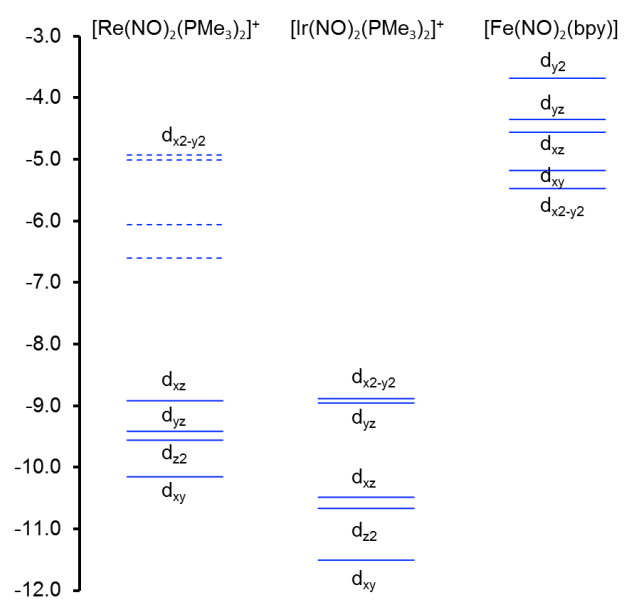

Figure 4. Kohn-Sham MO energy level (eV) diagram for $\left[\operatorname{Re}(\mathrm{NO})_{2}\left(\mathrm{PMe}_{3}\right)_{2}\right]^{+},\left[\operatorname{Ir}(\mathrm{NO})_{2}\left(\mathrm{PMe}_{3}\right)_{2}\right]^{+}$, and $\left[\mathrm{Fe}(\mathrm{NO})_{2}(\right.$ bipy $\left.)\right]$. Occupied and unoccupied MOs are represented by solid and dotted lines, respectively.

A more subtle point concerns why all $\left\{\mathrm{M}(\mathrm{NO})_{2}\right\}^{10}$ complexes do not adopt a repulso conformation. Careful examination of the above $\mathrm{a}_{1}$-symmetry MO suggests that the strength of the metal $\left(\mathrm{d}_{\mathrm{x} 2-\mathrm{y} 2}\right)-\mathrm{NO}\left(\pi^{*}\right)$ orbital interaction should depend strongly on the size as well as the orbital energy of the metal $\mathrm{d}$ orbital; thus, larger $4 \mathrm{~d}$ and $5 \mathrm{~d}$ orbitals should lead to a stronger interaction relative to a smaller 3d orbital. Such a 'mechanism' also explains why this orbital interaction is less effective for first transition metals, in particular for pseudotetrahedral $\left\{\mathrm{M}(\mathrm{NO})_{2}\right\}^{9-10}$ complexes. ${ }^{17^{19}}$ An earlier discussion by Martin and Taylor correctly identified the prevalence of the repulso conformation among second- and third-row transition metal dinitrosyls, but also went overboard in essentially ruling out such a conformation for first-row transition metals. ${ }^{13}$ In fact, numerous borderline to nominally repulso conformations are now known pseudotetrahedral $\left\{\mathrm{M}(\mathrm{NO})_{2}\right\}^{10}(\mathrm{M}=\mathrm{Fe}, \mathrm{Co})$ complexes with soft supporting ligands such as phosphines and thioethers (including NODKEY, ${ }^{20}$ MIXDII, ${ }^{60}$ IJOLEZ $^{61}{ }^{\text {FOJHOB }},{ }^{62}$ ENOZAK $^{63}$ and DPPNFE ${ }^{64}$ for $\mathrm{Fe}$ and $\mathrm{CAXRIC}{ }^{21}$ and $\mathrm{NEZHIK}^{65}$ for $\mathrm{Co}$ ).

\section{Conclusion}

A great virtue of MO arguments is that under favorable circumstances they lead to the formulation of simple rules of thumb, which synthetic chemists can draw upon to create new molecules. True to that ideal, the present exercise has afforded the following simple thumb rules for predicting attracto and repulso dinitrosyl complexes. 
(1) Four- and five-coordinate $\left\{\mathrm{M}(\mathrm{NO})_{2}\right\}^{8}$ complexes are expected to provide paradigmatic examples of the cis-attracto conformation.

(2) Pseudotetrahedral $\left\{\mathrm{M}(\mathrm{NO})_{2}\right\}^{10}$ complexes involving $4 \mathrm{~d}$ and $5 \mathrm{~d}$ transition metals may be expected to exhibit a repulso or borderline conformation with unusually wide $\mathrm{NMN}^{\prime}$ angles.

(3) Pseudotetrahedral $\left\{\mathrm{M}(\mathrm{NO})_{2}\right\}^{9-10}$ complexes involving 3d transition metals, are more variable and may exhibit both attracto and repulso-like/borderline conformations, depending on the hard/soft character of the supporting ligands.

\section{Computational methods}

All calculations were carried out with the OLYP 27,28 exchange-correlation functional, with relativistic effects taken into account via the zeroth order regular approximation (ZORA) $)^{66,67,68}$ to the two-component Dirac equation, applied both as a scalar correction, ZORA STO-TZP basis sets, and tight convergence criteria, all as implemented in the Amsterdam Density Functional (ADF 2016) $)^{69,70}$ program system.

Supporting Information Available. Optimized Cartesian coordinates (10 pages).

Acknowledgements. This work was supported by the Research Council of Norway (grant no. 262229 to AG) and the South African National Research Foundation (grant nos. 113327 and 96111 to JC). 


\section{References}

(1) Ghosh, A. (ed.) The Smallest Biomolecules: Diatomics and their Interactions with Heme Proteins, Elsevier, 2008, pp 1-603.

(2) Hunt, A. P.; Nicolai, L. Heme-Nitrosyls: Electronic Structure Implications for Function in Biology. Acc. Chem. Res., 2015, 48, 2117-2125.

(3) Ghosh, A. Metalloporphyrin-NO Bonding: Building Bridges with Organometallic Chemistry. Acc. Chem. Res. 2005, 38, 943-954.

(4) Wyllie, G. R. A.; Scheidt, W. R. Solid-State Structures of Metalloporphyrin $\mathrm{NO}_{\mathrm{x}}$ Compounds. Chem. Rev. 2002, 102, 1067-1090.

(5) Mingos, D. M. P. Historical Introduction to Nitrosyl Complexes. Struct. Bond. 2014, 153, 144.

(6) Tsai, M.-L.; Tsou, C.-C.; Liaw, W.-F. Dinitrosyl Iron Complexes (DNICs): From Biomimetic Synthesis and Spectroscopic Characterization toward Unveiling the Biological and Catalytic Roles of DNICs. Acc. Chem. Res. 2015, 48, 1184-1193.

(7) Pulukoddy, R.; Darensbourg, M. Y. Synthetic Advances Inspired by the Bioactive Dinitrosyl Iron Unit. Acc. Chem. Res. 2015, 48, 2049-2058.

(8) Crack, J. C.; Green, J.; Thomson, A. J.; Brun, N. E. L. Iron-Sulfur Clusters as Biological Sensors: The Chemistry of Reactions with Molecular Oxygen and Nitric Oxide. Acc. Chem. Res. 2014, 47, 3196-3205.

(9) Fitzpatrick, J.; Kim E. Synthetic Modeling Chemistry of Iron-Sulfur Clusters in Nitric Oxide Signaling". Acc. Chem. Res. 2015, 48, 2453-2461.

(10) Vanin, A. F. Dinitrosyl iron complexes with thiol-containing ligands as a "working form" of endogenous nitric oxide. Nitric Oxide 2016, 44, 15-29.

(11) Enemark, J. H.; Feltham, R. D. Principles of Structure, Bonding and Reactivity for Metal Nitrosyl Complexes. Coord. Chem. Rev. 1974, 13, 339-406.

(12) Canfield, P. J.; Blake, I. M.; Cai, Z.-L.; Luck, I. J.; Krausz, E.; Kobayashi, R.; Reimers, J. R.; Crossley, M. J. A new fundamental type of conformational isomerism. Nat. Chem. 2018, 10, 615624.

(13) Martin, R. L.; Taylor, D. Bending of Linear Nitric Oxide Ligands in Four-Coordinate Transition Metal Complexes. Crystal and Molecular Structure of Dinitrosyldithioacetylacetonatocobalt(-I), Co(NO) 2 (SacSac). Inorg. Chem. 1976, 15, 2970-2976. 
(14) Nietlispach, D.; Bosch, H. W.; Berke, H. A. Comparative Study of the Reactivity of $\mathrm{Mn}(\mathrm{NO})_{2} \mathrm{~L}_{2} \mathrm{H}$ and $\mathrm{Mn}(\mathrm{CO})_{3} \mathrm{~L}_{2} \mathrm{H}$ Complexes $(\mathrm{L}=$ Phosphorus Donor). Eur. J. Inorg. Chem. 1994, 127, 2403-2415.

(15) Jacobsen, H.; Heinze, K.; Llamazares, A.; Schmalle, H. W.; Artus, G.; Berke, H.

Coordination chemistry of the $\left[\mathrm{Re}(\mathrm{NO})_{2}\left(\mathrm{PR}_{3}\right)_{2}\right]^{+}$fragment: crystallographic and computational studies. J. Chem. Soc. Dalton Trans. 1999, 0, 1717-1728.

(16) Michael, D.; Mingos, P.; Sherman, D. J.; Bott, S. G. A structural and n.m.r. investigation of chlorodinitrosyl bis(triphenyl phosphine) osmium(1+) tetrafluoroborate, $\left[\mathrm{OsCl}(\mathrm{NO})_{2}\left(\mathrm{PPh}_{3}\right)_{2}\right] \mathrm{BF}_{4}$. Transition Met. Chem. 1987, 12, 471-475.

(17) Tonzetich, Z. J.; Do, Loi H.; Lippard, S. J. Dinitrosyl Iron Complexes Relevant to Rieske Cluster Nitrosylation. J. Am. Chem. Soc., 2009, 131, 7964-7965.

(18) Tsai, F.; Kuo, T.; Liaw, W.; Dinitrosyl Iron Complexes (DNICs) Bearing O-Bound Nitrito Ligand: Reversible Transformation between the Six-Coordinate $\left\{\mathrm{Fe}(\mathrm{NO})_{2}\right\}^{9}\left[(1-\mathrm{MeIm}) 2\left(\eta^{2}-\right.\right.$ $\left.\mathrm{ONO}) \mathrm{Fe}(\mathrm{NO})_{2}\right](g=2.013)$ and Four-Coordinate $\left\{\mathrm{Fe}(\mathrm{NO})_{2}\right\}^{9}\left[(1-\mathrm{MeIm})(\mathrm{ONO}) \mathrm{Fe}(\mathrm{NO})_{2}\right](g=$ 2.03). J. Am. Chem. Soc. 2009, 131 3426-3427.

(19) Wang, R.; Wang, X.; Sundberg, E. B.; Nguyen, P.; Grant, G. P. G.; Sheth, C.; Zhao, Q.; Herron, S.; Kantardjieff, K. A.; Li, L. Synthesis, Structures, Spectroscopic and Electrochemical Properties of Dinitrosyl Iron Complexes with Bipyridine, Terpyridine, and 1,10-Phenathroline. Inorg. Chem. 2009, 48, 9779-9785.

(20) Holloway, L. R.; Clough, A. J.; Li, J. Y.; Tao, E. L.; Tao, F.; Li, L. A combined experimental and theoretical study of dinitrosyl iron complexes containing chelating bis(diphenyl)phosphinoX ( $\mathrm{X}=$ benzene, propane and ethylene): X-ray crystal structures and properties influenced by the presence or absence of $\pi$-bonds in chelating ligands. Polyhedron 2014, 70, 29-38.

(21) Lanfredi, A. M. M.; Tiripicchio, A.; Camellini, M. T. Dinitrosylbis(trimethyl phosphite)cobalt(-I) tetraphenylborate, $\left[\mathrm{Co}(\mathrm{NO})_{2}\left\{\mathrm{P}(\mathrm{OMe})_{3}\right\}_{2}\right]\left[\mathrm{BPh}_{4}\right]$. Acta Cryst. 1983, C39, 1633-1635.

(22) Haymore, B. L.; Ibers, J. A. Linear vs. bent nitrosyl ligands in four-coordinate transition metal complexes. Structure of dinitrosylbis(triphenylphosphine)osmium(-II) hemibenzene,

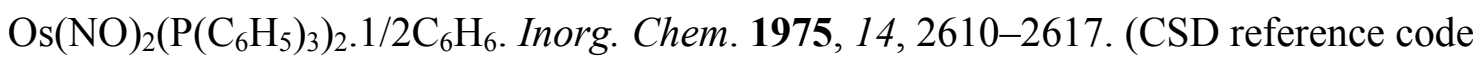
NTPOSB) 
(23) Kaduk, J. A.; Ibers, J. A. Structure of dinitrosyl(1,2-bis(diphenylphosphino)ethane)cobalt hexafluorophosphate, $\left[\mathrm{Co}(\mathrm{NO})_{2}\left(\left(\mathrm{C}_{6} \mathrm{H}_{5}\right)_{2} \mathrm{PC}_{2} \mathrm{H}_{4} \mathrm{P}\left(\mathrm{C}_{6} \mathrm{H}_{5}\right)_{2}\right)\right]\left[\mathrm{PF}_{6}\right]$. Inorg. Chem. 1977, 16, 32833287.

(24) Reichert. B. E. Dinitrosylbis(triphenylphosphine)cobalt hexafluorophosphate. Acta Cryst. 1976, B32, 193 four-1936.

(25) Kaduk, J. A.; Ibers, J. A. Crystal and molecular structure of dinitrosylbis(triphenylphosphine)rhodium perchlorate, $\left[\mathrm{Rh}(\mathrm{NO})_{2}\left(\mathrm{P}\left(\mathrm{C}_{6} \mathrm{H}_{5}\right)_{3}\right)_{2}\right]\left[\mathrm{ClO}_{4}\right]$. Inorg. Chem. 1975, 14, 3070-3073.

(26) Mingos, D. M. P.; Ibers, J. A. Crystal and molecular structure of

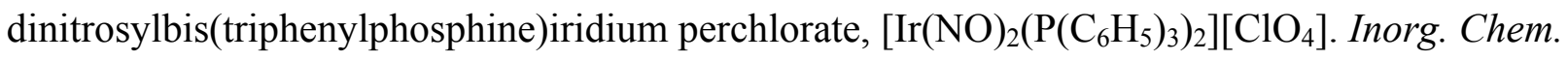
1970, 9, 1105-1111.

(27) Handy, N. C.; Cohen, A. Left-right correlation energy. J. Mol. Phys. 2001, 99, 403-412. (28) Lee, C.T.; Yang, W.T.; Parr, R.G. Development of the Colle-Salvetti correlation-energy formula into a functional of the electron-density. Phys. Rev. B, 1988, 37, 785-789.

(29) Swart, M.; Groenhof, A. R.; Ehlers, A.W.; Lammertsma, K. Validation of Exchange-Correlation Functionals for Spin States of Iron Complexes. J. Phys. Chem. A 2004, $108,5479-5483$.

(30) Swart, M.; Ehlers, A.W.; Lammertsma, K. Performance of the OPBE exchange-correlation functional. Mol. Phys. 2004, 102, 23-24.

(31) Conradie, J.; Ghosh, A. Electronic Structure of Trigonal-Planar Transition-Metal-Imido Complexes: Spin-State Energetics, Spin-Density Profiles, and the Remarkable Performance of the OLYP Functional. J. Chem. Theory Comput. 2007, 3, 689-702.

(32) Conradie, M.M.; Conradie, J.; Ghosh, A. J. Inorg. Biochem. 2011, 105, 84-91.

(33) Conradie, J.; Ghosh, A. DFT Calculations on the Spin-Crossover Complex Fe(salen)(NO): A Quest for the Best Functional. J. Phys. Chem. B 2007, 111, 12621-12624.

(34) Tangen, E.; Conradie, J.; Franz, K.; Friedle, S.; Telser, J.; Lippard, S. J.; Ghosh, A. Inorg. Chem. 2010, 49, 2701-2705.

(35) Hopmann, K.H.; Conradie J.; Ghosh, A. J. Phys. Chem. B 2009, 113, 10540-10547

(36) Hopmann, K. H.; Noodleman, L.; Ghosh, A. Spin Coupling in Roussin's Red and Black Salts. Chem. Eur. J. 2010, 16, 10397-10408. 
(37) Sandala, G. M.; Hopmann, K.H.; Ghosh, A.; Noodleman, L. Calibration of DFT Functionals for the Prediction of ${ }^{57} \mathrm{Fe}$ Mössbauer Spectral Parameters in Iron-Nitrosyl and Iron-Sulfur Complexes: Accurate Geometries Prove Essential. J. Chem. Theory Comput. 2011, 7, 3232-3247. (38) Hauser, C.; Weyhermüller, T.; Wieghardt, K. Reductive Nitrosylation of $\mathrm{V}_{2} \mathrm{O}_{5}$ and $\mathrm{MoO}_{3}$ with Hydroxylamine in the Presence of 1,4,7-Triazacyclononane. Collect. Czech. Chem. Commun. 2001, 66, 125-138.

(39) Wu, P.; Liu, S.; Shieh, Y.; Kuo, T.; Lee, G.; Wang, Y.; Tsai, Y. Divergent reactivity of nitric oxide with metal-metal quintuple bonds. Chem. Commun. 2013, 49, 4391-4393.

(40) Sellmann, D.; Seubert, B.; Kern, W;.Knoch, F.; Moll, M. Übergangsmetallkomplexe mit Schwefelliganden, LXI / Transition Metal Complexes with Sulfur Ligands, LXI. Z. Naturforsch. B: Chem. Sci. 1991, 46, 1435-1448.

(41) Elcesser, W. L., Sörlie, M.; Hubbard, J. L. Structure and Reactivity of ( $\eta$ $\left.\mathrm{C}_{5} \mathrm{R}_{5}\right) \mathrm{Mo}(\mathrm{NO})_{2}-$ Halide, - Halomethyl, and - Alkyl Complexes: Consecutive Aerobic Methylene and Nitrosyl Ligand Oxidation. Organometallics, 1996, 15, 2534-2542.

(42) Diebold, T.; Schappacher, M.; Chevrier, B.; Weiss, R. Low-valent molybdenum porphyrin derivatives: synthesis and X-ray crystal structures of dinitrosyl- and methanol(nitrosyl)-mesotetra-p-tolylporphyrinatomolydenum(II) benzene solvates. J. Chem. Soc., Chem. Commun. 1979, 0, 693-694.

(43) Tangen, E.; Ghosh, A. Electronic structure of $c i s-\mathrm{Mo}(\mathrm{P})(\mathrm{NO})_{2}$, where $\mathrm{P}$ is a porphyrin: An organometallic perspective of metalloporphyrin-NO complexes. J. Inorg. Biochem. 2005, 99, 959-962.

(44) Lorcovic, I.; Ford, P. C. Nitric Oxide Addition to the Ferrous Nitrosyl Porphyrins Fe(P)(NO) Gives trans-Fe(P)(NO) $)_{2}$ in Low-Temperature Solutions. J. Am. Chem. Soc. 2000, 122, 6516-6517. (45) Conradie, J.; Wondimagegn, T.; Ghosh, A. Molecular Structure and Conformation of Dinitrosylheme. J. Am. Chem. Soc. 2003, 125, 4968-4969.

(46) Patterson, J. C.; Lorkovic, I. M.; Ford, P. C. Spectroscopic and Density Functional Studies of the Dinitrosyl Metalloporphyrin Complexes $\mathrm{Fe}(\mathrm{P})(\mathrm{NO})_{2}$ and $\mathrm{Ru}(\mathrm{P})(\mathrm{NO})_{2}$. Inorg. Chem. 2003, 42, $16,4902-4908$.

(47) Goldner, M.; Geniffke, B.; Franken, A.; Murray, K. S.; Homborg, H. Mononitrosyl and transdinitrosyl complexes of phthalocyaninates of manganese and rhenium. Z. Anorg. Allg. Chem. 2001, 627, 935-947. 
(48) Tangen, E.; Conradie, J.; Svadberg, A.; Ghosh, A. Understanding the unexpected linearity of the trans- $\left\{\mathrm{Mn}(\mathrm{NO})_{2}\right\}^{8}$ unit in a phthalocyanine complex: some thoughts on dinitrosylheme intermediates in biology. J. Inorg. Biochem. 2005, 99, 55-59.

(49) Kekilli, D.; Petersen, C. A.; Pixton, D. A.; Ghafoor, D. D.; Abdullah, G. H.; Dworkowski, F. S. N.; Wilson, M. T.; Heyes, D. J.; Hardman, S. J. O.; Murphy, L. M.; Strange, R. W.; Scrutton, N. S.; Andrew, C. R.; Hough, M. A. Engineering proximal vs. distal heme-NO coordination via dinitrosyl dynamics: implications for NO sensor design. Chem. Sci. 2017, 8, 1986-1994.

(50) A single global minimum, corresponding to a specific conformation - attracto, repulso, or borderline - was found for each complex examined.

(51) DFT-based MO arguments have proved remarkably useful in explaining the linear, bent, or intermediate geometries of transition metal nitrosyls..$^{51^{-59}}$

(52) Tangen, E.; Conradie, J.; Ghosh, A. The Challenge of Being Straight: Explaining the Linearity of a Low-Spin $\{\text { FeNO }\}^{7}$ Unit in a Tropocoronand Complex. Inorg. Chem. 2005, 44, 8699-8706.

(53) Conradie, J.; Ghosh, A. When being straight bends rules: A rationale for the linear FeNO unit in the low-spin square-pyramidal $\left\{\mathrm{FeNO}^{7}\right.$ tetracyanonitrosylferrate(2-) anion. J. Inorg.

Biochem. 2006, 100, 2069-2073.

(54) Conradie, J.; Ghosh, A. Correlation between the FeNO Angle and d-p Mixing in $\{\mathrm{FeNO}\}^{7}$ Complexes.

(55) Conradie, J.; Quarless, D. A.; Hsu, H.-F.; Harrop, T. C.; Lippard, S. J.; Koch, S. A.; Ghosh, A. Electronic Structure and FeNO Conformation of Nonheme Iron-Thiolate-NO Complexes: An Experimental and DFT Study. J. Am. Chem. Soc. 2007, 129, 10446-10456.

(56) Conradie, J.; Hopmann, K.; Ghosh, A. Understanding the Unusually Straight: A Search For MO Insights into Linear $\{\mathrm{FeNO}\}^{7}$ Units. J. Phys. Chem. B 2010, 114, 8517-8524.

(57) Conradie, J.; Ghosh, A. Correlation between the FeNO Angle and d-p Mixing in $\{\text { FeNO }\}^{7}$ Complexes. Inorg. Chem. 2011, 50, 4223-4225

(58) Conradie, J.; Ghosh, A. Stereochemical Diversity of $\{\mathrm{MNO}\}{ }^{10}$ Complexes: Molecular Orbital Analyses of Nickel and Copper Nitrosyls. Inorg. Chem. 2014, 53, 4847-4855.

(59) Ye, S.; Neese, F. The Unusual Electronic Structure of Dinitrosyl Iron Complexes. J. Am. Chem. Soc. 2010, 132, 3646-3647. 
(60) Jones, M. W.; Powell, D. R.; Richter-Addo G. B. Synthesis, characterization, and fiber-optic infrared reflectance spectroelectrochemical studies of some dinitrosyl iron diphosphine complexes $\mathrm{Fe}(\mathrm{NO})_{2} \mathrm{~L}_{2}\left(\mathrm{~L}=\mathrm{P}\left(\mathrm{C}_{6} \mathrm{H}_{4} \mathrm{X}\right)_{3}\right)$. J.Organom. Chem. 2014, 754, 63-74.

(61) Jones, M. W.; Powell, D. R.; Richter-Addo G. B. Dinitro-sylbis[tris-(4chloro-phen-yl)phosphane]iron. Acta Cryst. 2011, E67, m247.

(62) Le Borgne, G.; Mordenti, L.; Riess, J. G.; Roustan, J.-L. CSD reference FOJHOB

(63) Wittkamp, F.; Nagel, C.; Lauterjung, P.; Mallick, B.; Schatzschneider, U.; Apfel, U.-P.

Phosphine-ligated dinitrosyl iron complexes for redox-controlled NO release. Dalton Trans. 2016, 45, 10271-10279.

(64) Albano, V. G.; Araneo, A.; Bellon, P. L.; Ciani, G.; Manassero, M. Stereochemistry of tetrahedral complexes of group VIII metals. Crystal and molecular structures of dinitrosylcarbonyltriphenylphosphineiron, $\mathrm{Fe}(\mathrm{NO})_{2}(\mathrm{CO})\left(\mathrm{PPh}_{3}\right)$, and of dinitrosylbis(triphenylphosphine)iron, $\mathrm{Fe}(\mathrm{NO})_{2}\left(\mathrm{PPh}_{3}\right)_{2}$. J. Organomet. Chem. 1974, 67, 413-422. (65) DuPont, J. A.; Coxey, M. B.; Schebler, P. J.; Incarvito, C. D.; Dougherty, W. G.; Yap, G. P. A.; Rheingold, A. L.; Riordan, C. G. High-Spin Organocobalt(II) Complexes in a Thioether Coordination Environment. Organometallics, 2007, 26, 971-979.

(66) van Lenthe, E.; Baerends, E. J.; Snijders, J. G. Relativistic regular two-component Hamiltonians. J. Chem. Phys. 1993, 99, 4597-4610.

(67) van Lenthe, E.; Baerends, E. J.; Snijders, J. G. Relativistic total energy using regular approximations. J. Chem. Phys. 1994, 101, 9783-9792.

(68) van Lenthe, E.; Ehlers, A.; Baerends, E. J. Geometry optimizations in the zero order regular approximation for relativistic effects. J. Chem. Phys. 1999, 110, 8943-8953.

(69) The ADF program system uses methods described in: Velde, G. T.; Bickelhaupt, F. M.; Baerends, E. J.; Guerra, C. F.; van Gisbergen, S. J. A.; Snijders, J. G.; Ziegler, T. J. Comput. Chem. 2001, 22, 931-967.

(70) For additional details on all aspects of the calculations, see the ADF program manual: http://www.scm.com/ADF/. 


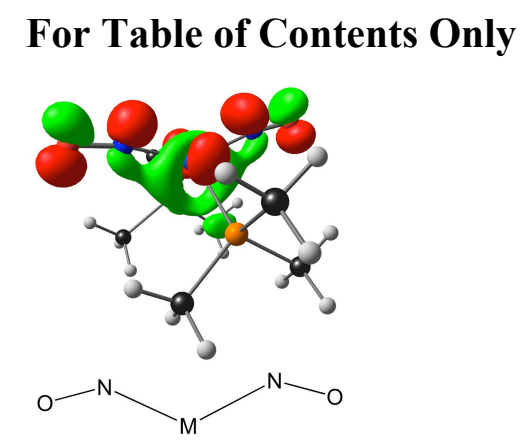

\section{Synopsis}

Modern DFT calculations have been employed for the first time to address the attracto/repulso structural dichotomy of transition metal dinitrosyl complexes. Simple rules of thumb now predict the occurrence of the two conformations. 